\title{
Social Validity of a Creative and Cognitive Enrichment Program for Gifted Children
}

\author{
Anayanzin Antonio-Cañongo, Guadalupe Acle-Tomasini, \\ Laura María Martínez-Basurto, Gabriela Ordaz-Villegas \\ Faculty of Higher Studies Zaragoza, National Autonomous University of Mexico, Mexico City, México \\ Email: yanzi.a c@hotmail.com, gaclet@unam.mx, martinezblmaria@yahoo.com.mx, \\ gabordaz@yahoo.com.mx
}

Received 30 June 2015; accepted 7 September 2015; published 10 September 2015

Copyright @ 2015 by authors and Scientific Research Publishing Inc.

This work is licensed under the Creative Commons Attribution International License (CC BY). http://creativecommons.org/licenses/by/4.0/

\section{Open Access}

\section{Abstract}

Identification of gifted children in Mexico has been limited. This population may be thus considered at educational risk, requiring that programs to enhance the development of their potential be implemented. Social validity will make it possible to learn to which extent procedures, goals and outcomes of implemented interventions are relevant and accepted by participants, in order to promote future interventions that serve as a protective factor for these students. The purpose of this study was to assess the educational significance, the acceptability of procedures, and the social effects of a creative and cognitive enrichment program for gifted children, their parents and teachers, based on the ecological risk/resilience model. In this descriptive non-experimental mixed-method design study, 15 children, 16 parents and 3 teachers participated, responding to different questionnaires. Results were analyzed quantitatively and qualitatively. Quantitatively, no statistically significant differences were found in responses of fathers and mothers regarding educational significance, assessment and intervention procedure acceptability, or social effects. Children, parents, and teachers considered their participation in this program to be useful, since they were provided with comprehensive assistance that not only enhanced the development of the children's potential, but also promoted interaction between school and family settings. The social validity of the creative and cognitive enrichment program based on the ecological risk/resilience model shows the development of resilient behaviors in children, parents and teachers that encourages the stimulation of these children's potential.

\section{Keywords}

Social Validity, Giftedness, Enrichment, Creativity, Ecological Risk/Resilience Approach 


\section{Introduction}

A giftedness category ${ }^{1}$ in Mexico was included in the special education field in the middle 80's as part of a six-year government program called Capacidad y Aptitud Sobresaliente (CAS) (Talent and Giftedness), which encouraged the identification and fulfillment of gifted-identified children's potential (Secretaría de Educación Pública [SEP], 2006), thereby recognizing that this population had special educational needs (SEN) that required specialized educational programs. However, programs aimed at gifted children in the country have been limited over the years because of a lack of a clear, specific conceptualization for proper identification and assistance (Zacatelco, 2005; Zavala, 2004), as well as the failure of the policies put in place, the lack of financial resources, the use of models that have not achieved tangible results as expected (Cortés, 2010), and changes in the way that the bodies be responsible for detection assess, or provide assistance (Acle, 2013a).

There are a large number of these children who have not been identified or assisted. Ordaz \& Acle (2010) estimate that $2.2 \%$ of school population is gifted based on the World Health Organization guidelines characterizing gifted individuals as having an Intelligence Quotient (IQ) of 130 or higher. When comparing this estimate to the 190,849 gifted students served by the Secretariat of Public Education (Secretaría de Educación Pública) (SEP, 2013), this population would only represent $0.54 \%$ of the aforementioned potential gifted population. Therefore, $1.66 \%$ of gifted students remain unidentified and thus unattended because not every school has the support from the bodies responsible for identification.

Moreover, Ordaz \& Acle (2012) highlight that this situation indicates how limited the identification process of these students population is at basic education levels and non-existent at higher levels of education. As a consequence, this group is considered to be vulnerable, especially those students that live in marginalized areas and have no real opportunities to access educational programs, added to the conditions they live in that limit or hinder the development of their potential (Llobet, 2005; Valadez, Betancourt, \& Zavala, 2012). Their intellectual and affective potential may be reduced as they take refuge in inadequate study habits (Valadez et al., 2012). Assessment will be a key tool for identification and allowing for SEN detection and in turn informed intervention decision-making (Sattler, 2003). Assessment for identification will depend on the chosen theoretical approach that will make possible the understanding of gifted students. Mason \& Mönks (2000) described four essential models: 1) abilities model; 2) achievement-oriented models; 3) cognitive models; and 4) socio-cultural model.

Some disadvantages of using the first three models lie in the notion that gifted potential is a fixed characteristic or the fact that specific components are given priority and the children who do not perform at high levels may be left out of timely identification and assistance. In addition, these models are mainly focused on individuals, but socio-cultural models are starting to take interactions between different external and intrachild factors or characteristics of children into account, which are positive (Blanco, 2001). That is the reason why detection should not be considered as a one-time process in students' lives but rather an ongoing process with different circumstances (Valadez et al., 2012). From this perspective, the ecological risk/resilience model in special education stresses that, when studying an individual, interactions between different environmental components must be taken into account since he/she is involved in many settings (Acle, 2006).

This model is based on the principle that human development occurs through interactions with the environment where there are rules that determine the final behavior of an individual (Bronfenbrenner, 1987). Assessment from this perspective emphasizes a vigorous, multi-dimensional evaluation, where traditional forms to assess are not rejected but integrated to provide an overview of interacting variables with the purpose of analyzing the relations between environmental and individual expectations to identify behaviors, settings and conditions suitable for intervention (Adelman \& Taylor, 1994; Swartz \& Martin, 1997). In order to understand a gifted child, it is necessary to evaluate the impact of interrelations within different contexts and the adaptation processes used in interaction settings. In this sense, a gifted child can be understood as a result of a variety of reciprocal interactions between individuals and environment.

Therefore, identification and assessment of gifted students under the ecological risk/resilience model will allow for a full understanding about the development of their knowledge and abilities, with the purpose of offering educational insight based on their characteristics and contexts (Chávez \& Zacatelco, 2012). That is, evaluation based on this model provides a baseline for analyzing the impact that individual, school, social, and contextual experiences have on gifted children's achievements, or other long-term educational needs. Moreover, it will help to create risk/protection profiles to facilitate the identification of behaviors, contexts, and conditions suitable for

\footnotetext{
${ }^{1}$ Official term in Mexico for referring to gifted or talented people.
} 
intervention to reduce risk factors and foster protective factors (Adelman \& Taylor, 1994; Swartz \& Martín, 1997).

Protective factors refer to an attribute of an individual or context, or interaction that predicts better outcomes, particularly in the presence of adversity. Risk factors refer to a characteristic of a group of individuals or a situation that is likely to lead to maladjustment in relevant areas, which helps to predict a negative outcome in a specific aspect (Masten, 2001; O’Dougherty \& Masten, 2006). As Acle (2012a) highlighted, the identification of a risk/protective profile from the moment the individual starts attending school (kindergarten or elementary school) is a relevant educational protective mechanism, since being gifted or talented is no guarantee of academic success. Therefore, appropriate or preventive programs will prevent these problems from arising and enable the development of a student's skills and potential (Hernández \& Borges del Rosal, 2005), so as to be able to intervene in a variety of aspects: prevention of more complex problems, reduction in the educational gap, and promotion of resilient behaviors that will help children to face their individual, family, school, and social vulnerabilities.

Ecological risk/resilience model intervention studies on gifted children living in marginalized conditions have proved some aspects that encourage the development of these children's potentialities, such as the usefulness of implemented intervention, and the promotion of collaborative work with parents and teachers. Among these are the studies conducted by Romero (2008), who, working with elementary school children identified as gifted under an ecological risk/resilience model, found that children showed an increase in creativity index and components, and self-awareness and self-regulation strategies; and collaborative work with parents and teachers was promoted. The latter recognized the importance and usefulness of programs implemented to benefit gifted children's learning.

Subsequently, Chávez, Zacatelco \& Acle (2009) successfully increased the total IQ ( $p=0.028)$, and the creativity index and indicators $(p=0.028)$ by implementing an enrichment creativity program through educational game activities in which six female elementary school students. Nevertheless, these authors noted a decrease in homework engagement, which was associated to the lack of interest and motivation that the girls showed towards school activities. By contrast, parents' awareness of their daughters' giftedness was indirectly enhanced, as well as the importance of providing them with additional resources for the development of their abilities, which resulted in a protective factor.

Similarly, by implementing an enrichment writing creativity program for six male gifted students from fifth and sixth grade, Zacatelco, Hernández, \& Acle (2012) found that students showed an increase in writing creativity through generating a story. They found appropriate self-esteem and confidence, and improvement in positive interpersonal relationships with their peers. In addition, the importance of including parents and teachers-who help reduce risk factors occurrence in school, family and social settings, and promote protective factors that foster effective school integration-in this type of programs was noticed.

While these studies show statistically significant differences between pre- and post-test IQ, creativity level, emotional aspects, and the like, it is important to highlight that there is little research on the long-term impact of any enrichment program (Shaughnessy \& Waggoner, 2015), and there are no social validity indicators for them. These are common limitations of intervention programs for gifted children (Bellamy, Gore, \& Sturgis, 2005; Chávez et al., 2009; Larraz \& Allueva, 2012; Márquez, 2010; Romero, 2008; Soriano, Galindo De Mata, Castellanos \& Vargas, 2010; Zacatelco et al., 2012). Therefore, it is important to use rigorous, systematic and objective procedures that help to obtain and validate possible relevant knowledge in the implementation of programs, which will in turn help in the development and promotion of giftedness in children (Cook, L., Cook, B., Landrum, \& Tankersley, 2008).

In this sense, social validity of intervention programs proves to be essential to providing information about scientific-evidence-based practices which in turn would contribute not only to the service of gifted children but also to addressing a range of special education problems (Acle, 2012b). Foster \& Mash (1999) note that treatment acceptability assessment is a broader issue than treatment viability, hence the relevance of learning how researchers transport their interventions to community settings. So social validity belongs to a strategy for assessing or measuring the social importance of goals, procedures, and outcomes of an intervention, since determining whether social needs are consistent with researchers' goals and expectations is required (Wolf, 1978).

Barrett, Shortt, Fox \& Wescombe (2001) refer to this concept as a process rather than a result, which can be assessed for program acceptability and viability at different stages during evaluation. Reynolds \& Fletcher-Janzen (2002) note that in educational contexts, social validity is the way in which psychological services are provided, which emphasizes the importance of subjective judgment regarding programs. These authors have agreed on the extension of social validity across the assessment of how acceptable and relevant for the participant population 
the procedures, goals, and outcomes of performed interventions are; consistently, Acle \& Ordaz (2014) highlight that social validity is focused on analyzing how goals, procedures and results are associated to a beneficial intervention to itself or targeted individuals, while the very program's objectives potential receives feedback in turn.

It is important to note that this concept has been traditionally applied to behavioral intervention research with the purpose of complementing measures of program effectiveness through social validation, providing the real significance of programs as perceived and evaluated by society (Foster \& Mash, 1999; Stahmer, Schreibman, \& Palardy, 2006). Stahmer et al. (2006) note that social validity enables the importance of intervention programs as perceived by society at large to be determined, promoting the identification of the variables affecting users' perceptions in a specific intervention and the understanding of programs that encourage better intervention strategies.

In addition, Acle (2013a) states that this procedure gives way to introspection into the functionality of some practices as well as the impact of a variety of contextual factors determining whether an intervention is successful. Accordingly, Reimers, Wacker, Derby, \& Cooper (1995) note that social validity helps to understand the relation between intervention and outcome acceptability. For this, it is common to establish the use of an array of methods; regulatory comparisons are typically made using quantitative methods and subjective evaluations are obtained by studying users' views through qualitative or quantitative reports, which provides more information about social validity than using a single method (Kramer, 2011). Regarding social validity assessment, Hawkins (1991) states that it is typically performed through surveys directed to both direct (students) and indirect (i.e. family members, teachers and/or community members) participants on their goal, procedure and outcome satisfaction with the programs in which they participated.

Authors like Fawcett (1991), Foster \& Mash (1999), and Schwartz \& Baer (1991) suggest the use of multiple informants, where participants of these programs have a fundamental role and are considered as the main source of information, since they will provide data on acceptability of programs and relevance in their implementation setting (Reimers, Wacker \& Koeppl, 1987; Stahmer et al., 2006). In agreement with Barrett et al. (2001), it is fundamental to know how consumers responded to comprehension easiness and aspect usefulness of the program, which contributes to treatment development. Moreover, by assessing treatment acceptability along with clinical trial results, highly efficient and viable interventions for the community are guaranteed. As aforementioned, the purpose of this study was to socially validate an ecological risk/resilience model-based creative and cognitive enrichment program for gifted children, and their parents and teachers in order to know its educational significance, the acceptability of procedures and its social importance.

\section{Method}

\subsection{Objectives}

1) To assess the educational significance of goals, procedures, and outcomes associated to the enrichment program.

2) To assess the acceptability of assessment and intervention procedures included in the implemented program regarding effectiveness of key activities of the programs and practical considerations.

3) To assess the social importance of outcomes and effects of change, including benefits for children, parents, and teachers, as well as the effects that were not incorporated directly as intervention objectives.

\subsection{Study Design}

A mixed design is proposed, with quantitative and qualitative data collection, analysis and mixing procedures being used (Creswell, 2015).

\subsection{Type of Study}

Descriptive, non-experimental; it does not involve significant comparison groups or conditions that did not receive treatment induced actively by the researcher (Cook, L. et al., 2008).

\subsection{Participants}

The intentional non-statistical sample consisted of: 
15 second- and third-graders from a public elementary school identified as gifted-11 girls and 4 boys $\left(\mathrm{M}_{\text {age }}=\right.$ 6 years). This students showed a high Intelligence Quotient (IQ) from 118 to 141 (IQ average $=125$ ), and high creativity and homework engagement levels.

12 mothers and 4 fathers $\left(M_{\text {age of mothers }}=37\right.$ years, and $M_{\text {age of fathers }}=45$ years $)$ with level of education ranging from junior high to undergraduate (1 with junior high level of education; 5 with high school level of education; 3 with a technical degree, and 7 with a Bachelor's degree). Relevant characteristics of families included: parents had an appropriate partner relationship with shared responsibilities and mutual support; they promoted household teamwork, respect, and communication between family members with the purpose of promoting family unity; they were involved in their children's education.

3 teachers-two second grade and one third grade teachers, with Bachelor's degrees on Education; ages 45, 59, and 39, and 16, 26, and 23 years of experience, respectively.

\subsection{Instruments}

- Cuestionario de Validación Social de Programas de Intervención en Educación Especial: Versión Padres (Acle-Tomasini, 2013b) (Social Validity Questionnaire on Especial Education Intervention Programs for Parents). It seeks to assess educational significance, acceptability, and social importance of programs relative to their goals, assessment and intervention procedures and effects. Consisting of a 25-statement Likert-like scale with response options from nothing (1), poorly (2), somewhat (3), very (4) to extremely (5). This instrument was submitted to experts for validation, which reached $90 \%$.

- Formato de valoración para los padres de familia respecto al programa de intervención (Antonio, 2014) (Intervention Program Rating Form for Parents). It was designed to gather parents' comments on the program in which they participated in terms of the following aspects: shared information and its usefulness. Section 1 of the form included questions about the way the topic was presented, the information that was shared, personal treatment, provided materials, and how questions were answered, with three possible responses: 1) satisfied, 2) neither satisfied nor dissatisfied, and 3) dissatisfied. Section 2 comprised open questions about learning during sessions and program usefulness.

- Formato de valoración para los docentes respecto al programa de intervención (Antonio, 2014) (Intervention Program Rating Form for Teachers). It aims at gathering information related to how the topic was presented and information, given; personal treatment; provided materials; and whether questions were answered, with three possible responses: 1) satisfied, 2) neither satisfied nor dissatisfied, and 3) dissatisfied. Additionally, it included two open questions about intervention program usefulness.

- Verbalizations of Children, Parents, and Teachers. At the end of the program, participants made comments on the program implementation. In addition, some ratings by teachers at ecological validity meetings, comments made by parents during sessions, and remarks by children throughout the program were picked up.

\subsection{Context and Setting}

The study was conducted in Iztapalapa borough of Mexico City, which is considered to be one of the most populated boroughs and presents the highest illiteracy rate (Arango \& Lara, 2005). It has the second highest crime rate in Mexico City by incidence rate (Procuraduría General de Justicia del Distrito Federal [PGJDF], 2012). An all-day public elementary school in this borough participated, which serves students in need of an extended stay at school, from 8:00 a.m. to 4:00 p.m.

\subsection{Procedure}

1) School officials, parents, and students identified as gifted were asked to give informed consent.

2) The creative and cognitive enrichment program was implemented and assessed. The cognitive aspect was divided into two parts. The first promoted abilities that enable children to be aware of, distinguish, and identify the information they were given, and the second encouraged abilities to process, organize, and apply the information they received from their settings. In the creative aspect, indicators of creativity (Torrance, 2008); fluency; flexibility; originality; and elaboration were encouraged in order to enable children to innovate, invent, create, and build or form original ideas or results. This program was implemented for 10 months, and consisted of 35 sessions lasting 60 minutes each; constant assessment was performed in each session for both aspects. 
3) A program for parents was concurrently implemented with the purpose of providing information resources and strategies that allowed them to understand their gifted children's educational needs, and to become aware of the importance of timely intervention and the development of their children's potential. Also, a program for teachers was implemented, which consisted of informative talks with the purpose of making teachers aware of the importance of identification and intervention for gifted children. Both programs were implemented for five sessions lasting 60 minutes each.

4) Upon the end of the programs, parents completed the Validación Social (Acle-Tomasini, 2013b) (Social Validity) questionnaire, and the intervention program rating form for parents (Antonio, 2014). In addition, verbalizations of teachers at ecological outcome validation meetings were gathered, as well as children's ratings of the program in which they participated.

\subsection{Analysis of Results}

Obtained data were quantitatively and qualitatively analyzed. Data from the social validity questionnaire for parents were analyzed using the SPSS version 20 software; a descriptive analysis of instrument items was performed. In order to identify statistically significant differences between fathers' and mothers' responses, the statistical nonparametric U-Mann Whitney test was used in each item. Data gathered from comments made by children, parents, and teachers on the implemented program were qualitatively analyzed.

\section{Results}

The social validity program results are listed in relation to the objectives mentioned.

\subsection{Educational Significance of Goals, Procedures, and Outcomes Associated to the Program}

Results showed that parents were satisfied with their participation in the program $\left(\mathrm{M}_{\text {total }}=4.3\right)$ because it helped them understand their children's educational needs and realize they could collaborate on their children's school learning; they saw significant changes in their children's learning and behavior; they highlighted that their children were more happy and motivated to go to school and the program contributed to their children's academic performance. These prove that the proposed program was educationally significant for parents in terms of goals, procedures, and outcomes. When comparing fathers' to mothers' responses in this regard, no statistically significant differences appeared (Table 1).

For teachers, the workshop offered was useful, valuable, and pleasant due to the fact that the information with which they were provided allowed them to help children; they described the sessions as productive and considered that the material reviewed would help them: 1) develop future plans; 2) improve teaching; 3) meet the special educational needs of every student, not only gifted ones; 4) become aware of the importance of servicing

Table 1. Education significance of goals, procedures, and outcomes associated to the intervention program.

\begin{tabular}{|c|c|c|c|c|c|}
\hline \multirow{2}{*}{ No. } & \multirow{2}{*}{ Indicator } & \multicolumn{3}{|c|}{ M Satisfaction (SD) $1=N, 5=E$} & \multirow{2}{*}{$\begin{array}{l}\text { U-Mann } \\
\text { Whitney. }\end{array}$} \\
\hline & & Total & Mothers & Fathers & \\
\hline 19 & $\begin{array}{l}\text { By participating in the program, my child learned } \\
\text { to do homework on his/her own. }\end{array}$ & $3.75(1.3)$ & $3.83(1.2)$ & $3.50(1.7)$ & $p=0.74$ \\
\hline 20 & I enjoyed attending the workshops provided to parents. & $4.75(0.44)$ & $4.75(0.45)$ & $4.75(0.50)$ & $p=1.0$ \\
\hline 21 & $\begin{array}{l}\text { Having discussions helped me understand my child's } \\
\text { educational needs. }\end{array}$ & $4.69(0.47)$ & $4.67(0.49)$ & $4.75(0.50)$ & $p=0.76$ \\
\hline 22 & $\begin{array}{l}\text { Changes in my child's school learning are significant } \\
\text { after attending the program. }\end{array}$ & $4.0(1.3)$ & $4.25(1.1)$ & $3.25(1.7)$ & $p=0.19$ \\
\hline 23 & $\begin{array}{l}\text { I realized that I too can work together with my child } \\
\text { in his/her academic learning. }\end{array}$ & $4.25(1.3)$ & $4.42(1.1)$ & $3.75(1.8)$ & $p=0.48$ \\
\hline 24 & After the program, my child is happy to go to school. & $4.19(1.3)$ & $4.33(1.1)$ & $3.75(1.8)$ & $p=0.63$ \\
\hline 25 & $\begin{array}{l}\text { With these programs, improvements in the academic } \\
\text { performance of students with needs are allowed for. }\end{array}$ & $4.81(.40)$ & $4.75(0.45)$ & $5.00(0.00)$ & $p=0.28$ \\
\hline
\end{tabular}

Note: Not at all $(\mathrm{N})=1$; Poorly $(\mathrm{P})=2$; Somewhat $(\mathrm{S})=3$; Very $(\mathrm{V})=4$; Extremely $(\mathrm{E})=5, p<0.05$ 
this population, as well as overcoming myths such as the assumption that children belonging to this population do not require special assistance or perform highly in school, always obtaining good grades-this is not always true, they may also perform poorly. It is important to note that teachers saw changes in their students after the program was completed; however, these changes were more noticeable in some students. The educational significance is illustrated by their comments (Table 2).

Educational significance for children is revealed in the fact that, according to them, the examined contents contributed to their learning in class, encouraged the development of new abilities, and enhanced others. Children described that at the beginning of the intervention, they were concerned because they thought that by participating they would fall behind in their school activities; however, they reported that what they learned contributed to their classroom and problem-solving performance. They learned to work in a team to achieve goals together and expressed how sad they felt when the program was over, for they would no longer work with their team members and the psychologist (Table 3).

\subsection{Acceptability of Assessment and Intervention Procedures of the Program}

Parents found the assessment and intervention procedures proposed for their children $\left(\mathrm{M}_{\text {total }}=4.6\right)$ acceptable and the language, precise and appropriate, and expressed that they were very satisfied regarding available information and improvement in their children's learning needs. Also, they enjoyed the continuous communication with psychologists during the implementation of the program and thus will recommend other parents to approve this type of programs. However, a minority of them found the duration of the program to be inappropriate, and believe that it did not last long enough and it should be extended up to sixth grade. It is important to mention that no significant differences were distinguished between fathers' and mothers' responses regarding acceptability (Table 4).

Table 5 shows some comments made by mothers that illustrate positive acceptability of the assessment and intervention procedures. Teachers stated that understanding gifted children with a risk/resilience model approach allowed them to understand how settings impact children's learning and to become aware of the importance of identifying risk and protective factors that foster or hinder their development in those settings and thus address the special educational needs of children in order to enable their potential development. They acknowledged the importance of early identification of these students to provide them with better educational opportunities. They generally reported to have enjoyed taking part in the evaluation process, in which their observations were heard, and said they would like these meetings to be held regularly because they find having an experts' input to guide and advice on their teaching practice very helpful.

Children in turn showed interest and were pleased by activities during each program session. They reported to feel "very well" and "happy" when participating in the program and to have had fun during activities they like the most such as treasure hunt, drawing, performing experiments, building objects, painting and/or drawing; they did not enjoyed activities related to writing. Students reported to be very happy with the psychologist that implemented the program because she would let them do fun activities, listen to their ideas and opinions.

\section{Table 2. Comments from teachers about noticeable changes in students.}

\begin{tabular}{cc}
\hline Teacher & Comment \\
\hline Teacher A & "I’ve seen improvement in my student; she pays more attention during activities." \\
Teacher B & "He is more focused during activities and finishes assignments on time.” \\
Teacher C & "She prefers manual activities and doesn't work very much in the classroom.” \\
\hline
\end{tabular}

Table 3. Verbalizations of children by the end of the creative and cognitive enrichment program.

\begin{tabular}{cl}
\hline Student & Verbalizations \\
MP & $\begin{array}{c}\text { "I was very happy, even though I missed some homework in school. But being here in psychology was very fun. } \\
\text { I liked it very much, being with the psychologist and my friends." }\end{array}$ \\
R & "We learned a lot. It was very fun. When I came, I did almost no homework, but I did do some, and it was very fun. \\
I want to come again." & "Psychology helped me a lot. I learned a lot and had a lot of fun." \\
\hline
\end{tabular}


Table 4. Assessment and intervention procedure acceptability of the intervention program.

\begin{tabular}{|c|c|c|c|c|c|}
\hline \multirow{2}{*}{ No. } & \multirow{2}{*}{ Indicator } & \multicolumn{3}{|c|}{ M Satisfaction (SD) $1=\mathrm{N}, 5=\mathrm{E}$} & \multirow{2}{*}{$\begin{array}{l}\text { U-Mann } \\
\text { Whitney }\end{array}$} \\
\hline & & Total & Mothers & Fathers & \\
\hline 1 & Assessment procedures that were first explained to me were clear. & $4.44(0.51)$ & $4.42(0.51)$ & $4.50(0.57)$ & $p=0.77$ \\
\hline 2 & $\begin{array}{l}\text { These procedures were a useful way to know the educational needs } \\
\text { of my child. }\end{array}$ & $4.75(0.44)$ & $4.83(0.38)$ & $4.50(0.57)$ & $p=0.19$ \\
\hline 3 & The language used for describing the results of the assessment was precise. & $4.69(0.47)$ & $4.67(0.49)$ & $4.75(0.50)$ & $p=0.76$ \\
\hline 4 & $\begin{array}{l}\text { After the assessment, I was instructed in ways to improve } \\
\text { my child's learning. }\end{array}$ & $4.62(0.61)$ & $4.67(0.49)$ & $4.50(1.0)$ & $p=1.0$ \\
\hline 11 & I enjoyed the continuous communication with instructors during the program. & $4.81(0.40)$ & $4.83(0.38)$ & $4.75(0.50)$ & $p=0.72$ \\
\hline 12 & $\begin{array}{l}\text { I was pleased that these programs were implemented } \\
\text { when children started attending elementary school. }\end{array}$ & $4.69(0.47)$ & $4.58(0.51)$ & $5.00(0.00)$ & $p=0.13$ \\
\hline 13 & Duration of program was appropriate. & $4.06(1.06)$ & $4.58(0.51)$ & $5.00(0.00)$ & $p=0.89$ \\
\hline 16 & $\begin{array}{l}\text { It is desirable to implement programs like this in } \\
\text { other grades in elementary school. }\end{array}$ & $4.81(0.40)$ & $4.75(0.45)$ & $5.00(0.00)$ & $p=0.28$ \\
\hline 17 & I agree to be informed about the reach of my child's educational needs. & $4.81(0.40)$ & $4.73(0.46)$ & $5.00(0.00)$ & $p=0.28$ \\
\hline
\end{tabular}

Note: Not at all $(\mathrm{N})=1$; Poorly $(\mathrm{P})=2$; Somewhat $(\mathrm{S})=3$; Very $(\mathrm{V})=4$; Extremely $(\mathrm{E})=5$.

Table 5. Comments from mothers on assessment and intervention procedures.

\begin{tabular}{cl}
\hline \multicolumn{1}{c}{ Tutors } & Comments \\
\hline "I just want to thank and congratulate them for their great ability and training as psychologists, and con- \\
ducting in an exceptional way this kind of programs." \\
"The screening procedure and the program were appropriate. The language used by psychologists was \\
precise, answering our questions efficiently. Children were satisfied and happy with how they were \\
treated. As parents, we highlight the work and beneficial outcomes of this project."
\end{tabular}

\subsection{Social Importance of Outcomes and Change Effects}

Parents reported that the proposed program reported some educational advantages for their children and that changes in behavior were evident since the assessment was performed. Some parents reported that their relationship with their child's teacher indirectly improved and/or their perception of their child's performance in class changed; they agreed upon the fact that being informed about their children's learning needs is very important for education purposes, and no significant differences were found between fathers' and mothers' responses (Table 6). Parents acknowledged the social importance of outcomes and effects of the program $\left(\mathrm{M}_{\text {total }}=\right.$ 4.2), since this not only helped children, parents, and teachers, but also decreased educational risk.

The social importance of this program is reinforced because the latter allowed parents the following as reported by them on the comments: to understand their child's characteristics and behavior; to be more sensible about their child's feelings, as well as their special educational needs; to be aware of the relevance of encouraging the development of their potential and promoting aspects such as creativity and reflection; to become aware of the importance of spending quality time and promoting communication with their children and identifying detrimental actions for interaction and communication, as well as strengthening behaviors such as becoming interested in the activities they like; being more patient and tolerant; listening to them; allowing them to express themselves; and valuing their feelings and ideas (Table 7).

Teachers agreed that the program allowed them to get to know and be aware of the variety of special educational needs found in the classroom and the importance of being well informed to promote timely assistance (Table 8). They recognized the program as a means to provide assistance to children with educational needs that are not identified or assisted at school. Understanding and awareness about the importance of timely identification and intervention to meet students' special educational needs were enabled, and teachers distinguished whether the strategies they used foster the development of children's abilities. Another aspect to which the enrichment program contributed was the acknowledgement of the importance of collaboration between family members, students, and teachers, which allowed them to understand the reason why family and school contexts are included in this program for their children's potential development. 
Table 6. Social importance of outcomes and change effects.

\begin{tabular}{|c|c|c|c|c|c|}
\hline \multirow{2}{*}{ No. } & \multirow{2}{*}{ Indicator } & \multicolumn{3}{|c|}{ M Satisfaction (SD) $1=\mathrm{N}, 5=\mathrm{E}$} & \multirow[t]{2}{*}{$\begin{array}{l}\text { U-Mann } \\
\text { Whitney }\end{array}$} \\
\hline & & Total & Mothers & Fathers & \\
\hline 5 & I noticed changes in my child's behavior during the entire assessment. & $4.06(1.1)$ & $4.25(1.1)$ & $3.50(1.29)$ & $p=0.23$ \\
\hline 6 & $\begin{array}{l}\text { For educational purposes, it is important to be informed about our } \\
\text { children's learning needs. }\end{array}$ & $4.88(0.34)$ & $4.91(0.30)$ & $5.00(0.00)$ & $p=0.39$ \\
\hline 7 & $\begin{array}{l}\text { The service program suggested after the assessment reported educa- } \\
\text { tional advantages for my child. }\end{array}$ & $4.56(0.62)$ & $4.67(0.49)$ & $4.25(0.95)$ & $p=0.39$ \\
\hline 8 & By attending this program, my child's performance in class changed. & $4.13(0.95)$ & $4.33(0.77)$ & $3.50(1.2)$ & $p=0.19$ \\
\hline 9 & $\begin{array}{l}\text { Approval for my child to attend the program improved my relationship } \\
\text { with my child's teacher. }\end{array}$ & $3.63(1.3)$ & $3.83(1.1)$ & $3.00(1.8)$ & $p=0.41$ \\
\hline 10 & I would recommend other parents to approve this kind of program. & $4.88(0.34)$ & $4.83(0.38)$ & $5.00(0.00)$ & $p=0.39$ \\
\hline 14 & $\begin{array}{l}\text { Details about my child's educational needs changed what I thought } \\
\text { about his/her performance in class. }\end{array}$ & $4.25(1.1)$ & $4.17(1.1)$ & $4.50(1.0)$ & $p=0.54$ \\
\hline 15 & $\begin{array}{l}\text { During the entire program, my child's relationships with his/her } \\
\text { classmates improved. }\end{array}$ & $4.06(0.99)$ & $4.33(0.77)$ & $3.25(1.2)$ & $p=0.09$ \\
\hline 18 & $\begin{array}{l}\text { During the time my child participated in the program, his/her behavior } \\
\text { at home improved. }\end{array}$ & $3.75(1.3)$ & $4.00(1.2)$ & $3.00(1.8)$ & $p=0.31$ \\
\hline
\end{tabular}

Note: Not at all $(\mathrm{N})=1$; Poorly $(\mathrm{P})=2$; Somewhat $(\mathrm{S})=3$; Very $(\mathrm{V})=4$; Extremely $(\mathrm{E})=5$.

Table 7. Comments from parents about the intervention program benefits.

\begin{tabular}{cl}
\hline \multicolumn{1}{c}{ Parents } & \multicolumn{1}{c}{ Comments } \\
\hline Mother of a second-grade female student & $\begin{array}{l}\text { "It made me appreciate my child's abilities and learn how to make the most of them rather } \\
\text { than seeing them as something adverse." } \\
\text { "It helped me understand my daughter's abilities better." } \\
\text { Father of a second-grade female student }\end{array}$ \\
Mother of a third-grade female student & $\begin{array}{l}\text { "I learned to be more sensible about my daughter's feelings and needs during this stage of } \\
\text { development." } \\
\text { "Because it contributes to my daughter's mental development and served as other source of } \\
\text { Fupport to succeed." }\end{array}$ \\
\hline
\end{tabular}

Table 8. Comments from teachers about the intervention program benefits.

\begin{tabular}{cc}
\hline Teachers & Comments \\
\hline Teacher A & "It provides me with sufficient elements to continue my teaching work and not give up.” \\
Teacher B & "It is very helpful and pleasant to have this information in order to help children with these characteristics.” \\
Teacher C & "I find it very helpful to have more strategies to help these students develop.” \\
\hline
\end{tabular}

Table 9. Verbalizations of children about program benefits.

\begin{tabular}{cl}
\hline Student & Verbalizations \\
\hline C. & "I had a lot of fun, and I think everything we learned in psychology helped me." \\
I & $\begin{array}{c}\text { "I enjoyed being in psychology and learning lots of things. I had a lot of fun. I feel very good, I learned about } \\
\text { cause-and-effect, to distinguish. I mean, I did know some things already, but I learned more, I learned lots of things." }\end{array}$ \\
\hline
\end{tabular}

Children considered that the program allowed them to learn new things, as well as reinforce previous knowledge, which indicates its social importance, since this gained knowledge was reported to help them at school (Table 9). Benefits from participation in this program for children were identified by intraindividual repeated measures analysis through significant increase in Executive Intelligence Quotient in eight students $\left(\mathrm{F}_{(1,14)}=0.24\right.$ $p<0.05)$ and the creativity area in thirteen students $\left(\mathrm{F}_{(1,14)}=0.001, p<0.05\right)$. Moreover, children's reflection and argumentation skills were encouraged, as well as good behavior in the classroom and at home. It is important to highlight other effects such as changes in parents and teachers that affected children indirectly by recognizing their characteristics, taking interest in meeting children's educational needs, and committing to develop 
their potential in order to prevent it from vanishing. That is, changes occurred in the interactions between children and their closest settings-school and family.

\section{Discussion and Conclusions}

Parents, teachers, and children can be considered to have acknowledged the viability and acceptability of the proposed intervention (Barrett et al., 2001). In this sense, parents expressed to be satisfied with the assessment and intervention procedures used, as well as the outcomes, as they were able to: 1) understand their children's characteristics; 2) become aware of the importance of timely identification and assistance for meeting their educational needs; and 3) produce changes in their children's behavior at school and home. Therefore, the intervention was considered to be helpful and beneficial for their children, as they further mentioned that this type of assistance programs should be implemented throughout elementary school. These perceptions show relevance and significance of the program for parents, which provide a baseline to enhance improved intervention strategies (Stahmer et al., 2006).

No statistically significant differences between fathers and mothers were found regarding educational significance, procedure acceptability, or social impact elements; this asserts the social validity of the program. It is important to highlight that most of the parents had a higher level of education, formed well-united families, with an appropriate partner relationship with shared responsibilities and mutual support; also, they were involved and committed to their children's education. All of these aspects serve as protective factors for this population and contribute to the acceptability and functionality of the implemented program due to influence of family on children's learning, attitudes, and other aspects of their development as human beings (Valadez et al., 2012).

Teachers also reported to be satisfied with procedures, provided information and outcomes of the proposed intervention, as they considered this type of interventions to be very helpful in providing a means to contribute to the identification and intervention process for the development of their students' potential, since a relevant element for student success consists in becoming interested in meeting children's educational needs (Piske, Stoltz, \& Machado, 2014; Shaughnessy \& Waggoner, 2015). Furthermore, the implementation of these types of programs was considered key, as well as having professional guidance in teaching practice, because lack of information was considered to limit understanding about the implications of teaching gifted children, and thus promoting the development of their potential (Valadez et al., 2012), or else this would be a risk factor for said population.

Gifted children also reported to be satisfied and happy with their participation in the program and to have learned and had fun concurrently. Improvement of their creative and cognitive skills by the program was shown, as well as their interactions in family and school settings; therefore, this program became a protective factor for them since it enabled identification and assistance, which in turn may prevent complex problems and promote resilience behaviors that will allow children to face the individual, family and school vulnerabilities that they experience (Acle, 2012a). This also will prevent them from taking refuge in inadequate study habits and their potential from decreasing (Valadez et al., 2012), or they could find themselves in an at-risk situation.

In addition, based on adequate understanding and assistance in children's settings, the ecological risk/resilience model of this program promotes comprehensive intervention that benefit not only students but also parents and teachers, a decrease of risk factors, an increase of protective factors, and resilient behaviors (Acle, 2012b) as asserted by this study. Moreover, with this model, a gifted child is understood as a result of a variety of reciprocal interactions between individuals and environments. The social validity of this model and the programs originated therefrom is asserted by findings.

This creative and cognitive enrichment program for gifted children, their parents, and teachers showed high levels of satisfaction and positive ratings by participants, which means that intervention goals were significant, the procedures used, appropriate, and outcomes, relevant to participants (Acle \& Ordaz, 2014; Reynolds \& Fletcher-Janzen, 2002; Stahmer et al., 2006; Wolf, 1978). Therefore, this program could be considered as an alternative to attend to this population and provide evidence for future intervention planning. In conclusion, the proposed intervention was well accepted by participants, and efforts in attending to this population are socially valid.

\section{Limitations and Directions for Future Research}

A main limitation of this study is that even though the educational significance, the acceptability of procedures, 
and the social effects of a creative and cognitive enrichment program for gifted children, their parents and teachers, based on the ecological risk/resilience were evaluated; it had been made in a global way. In future research it will be important to introduce specific measures of the different skills targeted in the program for creative activities as well as cognitive ones, this may provide essential information about the social importance of outcomes and effects of benefits for children, parents and teachers. Also, in agreement with Cook, Tankersley \& Harjusola-Webb (2008), it will be relevant to include both scientific evidence-based practices and professional experience of those who implement programs in order to allow other special education professionals to lead their own interventions in school settings and achieve educational inclusion.

Another limitation of the study was that that some of the instruments make use of open questions to evaluate specific aspects of social validity, in future research it will be important to introduce specific measures to assess education significance, the acceptability of procedures and the social effects as they are perceived by children, parents and teachers. This have several implications as Barret et al. (2001) pointed out; participant's feedback will provide valuable information to be considered when designing or changing this kind of programs in special education. Also, this type of validate measures will provide information to pursue the stability of outcomes over the time.

An important issue is that programs implemented in natural settings must take into account that contextual factors could influence the outcomes of any intervention program in a dynamic manner. For example, the way in which inclusion policy is assumed by teachers in their classes and the level of knowledge they have about the special education categories must be acknowledged as well as parent's perceptions about their children learning and behavior. Future research would benefit from providing essential information about those factors as well as the resources required to achieve this kind of educative programs successfully, especially when parents and teachers accept to participate voluntarily in this kind of programs.

\section{Acknowledgements}

Project granted by the Programa de Apoyo a Proyectos de Investigación e Innovación Tecnológica (PAPIT) IN302812 (Support for Research and Innovation Projects Program IN302812).

\section{References}

Acle, G., \& Ordaz, G. (2014). Relevancia de la validez social y educativa de programas de intervención en educación especial [Relevance of Social and Educational Validity of Intervention Programs in Special Education]. Paper presented at the XXII Congreso Mexicano de Psicología: El papel del psicólogo en una sociedad violenta: Retos y aportaciones (17th Mexican Conference on Psychology: Psychologist Role in a violent society: Challenges and contributions), Veracruz, Mexico. Abstract from Conference Proceedings.

Acle, G. (2006). Educación especial: Investigación y práctica [Special Education: Research and Practice]. Mexico: Plaza y Valdés.

Acle, G. (2012a). Resiliencia en educación especial. Una experiencia en la escuela regular [Resilience in Special Education. An Experience in Elementary School]. Mexico: GEDISA-UNAM-FES Zaragoza.

Acle, G. (2012b). Validación social del modelo ecológico riesgo/ resiliencia en educación especial [Social Validity of the Ecological Risk/Resilience Model]. Cuarta Reunión Nacional de Investigación en Psicología (Fourth National Summit on Psychology Research). Sistema Mexicano de Investigación en Psicología (SMIP).

http://organicaeditores.mx/biblioteca/smip2012/contenido/resumenes/Psicologia_educativa/Guadalupe_Acle_Tomasini.pd $\underline{\mathrm{f}}$

Acle, G. (2013a). Investigación en educación especial (2002-2011): logros y desafíos [Research in Special Education (20022011): Achievements and Challenges]. In De Agüero, S.M. (Coord.), Aprendizaje y desarrollo 2002-2011 [Learning and Development 2002-2011] (pp. 20-109). Mexico: ANUIES.

Acle, G. (2013b). Cuestionario de validación social de programas de intervención en educación especial: Versión padres [Social Validity Questionnaire on Especial Education Intervention Programs for Parents]. Mexico: Universidad Nacional Autónoma de México.

Adelman, H. S., \& Taylor, L. (1994). On Understanding Intervention in Psychology and Education. Westport, CT: Praeger.

Antonio, A. (2014). Enriquecimiento cognitivo y creativo: Factor protector para los alumnos con aptitudes sobresalientes en zonas marginadas [Cognitive and Creative Enrichment: Protective Factor for Gifted Students in Disadvantaged Areas]. Unpublished Master's Thesis, Mexico: Universidad Nacional Autónoma de México.

Arango, A., \& Lara, C. (2005). Delegación Iztapalapa: Perfil sociodemográfico [Demographic Profile]. Análisis sobre la 
violencia social en la Delegación Iztapalapa [Analysis of social violence in Iztapalapa]. Instituto Ciudadanos de Estudios sobre la Inseguridad [Citizens Institute for Studies about Insecurity].

http://www.iztapalapa.df.gob.mx/pdf/SIBDSI/DIAGNOSTICO/iztapalapa_perfil_sociodemografico.pdf

Barrett, P. M., Shortt, A. L., Fox, T. L., \& Wescombe, K. (2001). Examining the Social Validity of the FRIENDS Treatment Program for Anxious Children. Behavior Change, 18, 63-77. http://dx.doi.org/10.1375/bech.18.2.63

Bellamy, A., Gore, D., \& Sturgis, J. (2005). Examining the Relevance of Emotional Intelligence within Educational Programs for the Gifted and Talented. Electronic Journal of Research in Educational Psychology, 3, 53-78. http://www.investigacion-psicopedagogica.org/revista/new/english/ContadorArticulo.php?68

Blanco, V. M. C. (2001). Guía para la identificación y seguimiento de alumnos superdotados [Guidance for Identification and Monitoring of Gifted Students]. Monografías escuela española [Monographs Spaniard School]. Valencia: Praxis.

Bronfenbrenner, U. (1987). La ecología del desarrollo humano [The Ecology of Human Development]. Barcelona: Paidós Ibérica.

Chávez, B. I., \& Zacatelco, F. (2012). Enriquecimiento de la creatividad: Alternativas para promover conductas resilientes en niños sobresalientes de segundo ciclo de primaria [Enrichment of Creativity: Alternatives to Promote Resilient Behaviors for Gifted Children of Second Cycle in Elementary School]. In T. G. Acle (Coord.), Resiliencia en educación especial. Una experiencia en la escuela regular regular [Resilience in Special Education. An Experience in Elementary School] (pp. 395-431). Mexico: GEDISA-UNAM-FES Zaragoza.

Chávez, B. I., Zacatelco, F., \& Acle, G. (2009). Programas de enriquecimiento de la creatividad para alumnas sobresalientes de zonas marginadas [Creativity Enrichment Program for Gifted Children from Disadvantaged Areas]. Electronic Journal of Research in educational Psychology, 7, 849-876.

Cook, B. G., Tankersley, M., \& Harjusola-Webb, S. (2008). Evidence-Based Special Education and Professional Wisdom: Putting It All Together. Intervention in School and Clinic, 44, 105-111. http://dx.doi.org/10.1177/1053451208321566

Cook, L., Cook, B., Landrum, T., \& Tankersley, M. (2008). Examining the Role of Group Experimental Research in Establishing Evidenced-Based Practices. Intervention in School and Clinic, 44, 76-82.

http://dx.doi.org/10.1177/1053451208324504

Cortés, L. (2010). Hacia una política pública de educación de talentos. El caso de México [Towards a Public Education Policy of Talents. The Case of Mexico]. Unpublished Doctoral Thesis, Costa Rica: Facultad Latinoamericana de Ciencias Sociales.

Creswell, J. (2015). Educational Research: Planning, Conducting, and Evaluating Quantitative and Qualitative Research. New York: Pearson.

Fawcett, S. B. (1991). Social Validity: A Note on Methodology. Journal of Applied Behavior Analysis, 24, 235-239. http://dx.doi.org/10.1901/jaba.1991.24-235

Foster, S. L., \& Mash, E. J. (1999). Assessing Social Validity in Clinical Treatment Research Issues and Procedures. Journal of Consulting and Clinical Psychology, 67, 308-319. http://dx.doi.org/10.1037/0022-006X.67.3.308

Hawkins, R. P. (1991). Is Social Validity What We Are Interested in? Argument for a Functional Approach. Journal of Applied Behavior Analysis, 24, 205-213. http://dx.doi.org/10.1901/jaba.1991.24-205

Hernández, J. M. C., \& Borges del Rosal, A. (2005). Un programa de aprendizaje autorregulado para personas de altas capacidades mediante herramientas telemáticas [A Self Regulated Learning Program for Gifted Students through Telemáticas Tools]. Electronic Journal of Research in Educational Psychology, 3, 233-252.

Kramer, J. M. (2011). Using Mixed Methods to Establish the Social Validity of a Self-Report Assessment: An Illustration Using the Child Occupational Self-Assessment (COSA). Journal of Mixed Methods Research, 5, 52-76. http://dx.doi.org/10.1177/1558689810386376

Larraz, R. N., \& Allueva, T. P. (2012). Efectos de un programa para desarrollar las habilidades creativas [Effects of a Program to Develop the Creative Skills]. Electronic Journal of Research Psychology, 10, 1139-1158.

Llobet, V. (2005). La promoción de la resiliencia en niños y adolescentes [Promote Resilience in Children and Adolescents]. Buenos Aires: Noveduc.

Márquez, N. (2010). Programa de intervención educativa para alumnos de educación secundaria con superdotación intelectual [Educational Intervention Program for High School Students with Intelectual Giftedness]. Ideacción, 31 , 20-33.

Mason, E., \& Mönks, F. (2000). Developmental Psychology and Giftedness: Theories and Research. In K. Heller, F. Mönks, R. Sternberg, \& R. Subotnik (Eds.), International Handbook of Giftedness and Talent (pp. 141-156). Oxford: Pergamon Press.

Masten, A. (2001). Ordinary Magic: Resilience Process in Development. American Psychologist, 56, 227-228. http://dx.doi.org/10.1037/0003-066X.56.3.227

O’Dougherty, W. M., \& Masten, S. A. (2006). Resilience Processes in Development. In S. Goldstein, \& R. B. Brooks (Eds.), 
Handbook of Resilience in Children (pp. 17-37). New York: Springer.

Ordaz, G., \& Acle, G. (2010). Importancia de la identificación de adolescentes sobresalientes [Importance of Identifying Gifted Younger]. Ideacción, 31, 321-328.

Ordaz, G., \& Acle, G. (2012). Perfil psicosocial de adolescentes con aptitudes sobresalientes de un bachillerato público [Psychosocial Profile of Gifted Adolescents of High Public School]. Electronic Journal of Research in Educational Psychology, 10, 1267-1298.

Piske, F. H. R., Stoltz, T., \& Machado, J. (2014). Creative Education for Gifted Children. Creative Education, 5, $347-352$. http://dx.doi.org/10.4236/ce.2014.55044

Procuraduría General de Justicia del Distrito Federal (PGJDF) (2012). Informe Estadístico Delictivo en el Distrito Federal [Report Criminal Statistical in Distrito Federal]. http://www.pgjdf.gob.mx/images/Estadisticas/2012.pdf

Reimers, T. M., Wacker D. P., Derby, M. K., \& Cooper, L. J. (1995). Relationship between Parental Attributions and the Acceptability of Behavioral Treatments for Their Child's Behavior. Behavioral Disorders, 20, 171-178.

Reimers, T. M., Wacker, D. P., \& Koeppl, G. (1987). Acceptability if Behavior Interventions: A Review of the Literature. School Psychology Review, 26, 212-227.

Reynolds, C. R., \& Fletcher-Janzen, E. (2002). Concise Encyclopedia of Special Education. A Reference for the Education of Handicapped and Exceptional Children and Adults. Hoboken, NJ: John Wiley \& Sons.

Romero, E. (2008). Modelo de atención para niños con aptitudes sobresalientes [Model of Service for Gifted Children]. Unpublished Master's Thesis, Mexico City: Universidad Nacional Autónoma de México.

Sattler, J. M. (2003). Evaluación infantil: Aplicaciones cognitivas. Volumen 1[Child Assessment: Cognitive Applications. Volume 1]. Mexico: Manual Moderno.

Schwartz, I. S., \& Baer, D. M. (1991). Social Validity Assessments: Is Current Practice State of The Art? Journal of Applied Behavior Analysis. Special Issue, Social Validity: Multiple perspectives, 24, 189-204. http://dx.doi.org/10.1901/jaba.1991.24-189

Secretaría de Educación Pública (2006). Propuesta de intervención: Atención educativa a alumnos y alumnas con aptitudes sobresalientes [Design Intervention: Educational Services to Gifted Students]. Mexico: SEP.

Secretaría de Educación Pública (2013). Primer Informe de Labores 2012-2013 [First Report of Work 2012-2013]. Mexico: SEP. http://fs.planeacion.sep.gob.mx/informes/labores/2012_2018/1er_informe_de_labores.pdf

Shaughnessy, M. F., \& Waggoner, C. (2015). How Rich Is Your Enrichment Program? Creative Education, 6, $663-668$. http://dx.doi.org/10.4236/ce.2015.67066

Soriano, M. E. I., Galindo, G. M. I., de Mata, C. E. C., Castellanos, S. D., \& Vargas, P. M. E. (2010). Taller de enriquecimiento personal-creativo con adolescentes de aptitudes sobresalientes [Personal-Creative Enrichment Workshop with Gifted Adolescents]. Ideacción, 31, 168-177.

Stahmer, A. C., Schreibman, L., \& Palardy, P. N. (2006). Social Validation of Symbolic Play Training for Children with Autism. Journal of Early and Intensive Behavior Intervention, 3, 196-210. http://dx.doi.org/10.1037/h0100332

Swartz, J. L., \& Martin, W. (1997). Applied Ecological Psychology for Schools within Communities. Hillsdale, NJ: Erlbaum.

Torrance, E. P. (2008). Torrance Tests of Creative Thinking: Norms-Technical Manual Figural (Streamlined) Forms A\&B. Benseville, IL: Scholastic Testing Service.

Valadez, M. D., Betancourt, J., \& Zavala, M. A. (2012). Alumnos superdotados y talentosos. Identificación, evaluación e intervención una perspectiva para docentes [Gifted and Talented Students. Identification, Assessment and Intervention Perspective for Teachers]. Mexico: Manual Moderno.

Wolf, M. M. (1978). Social Validity: The Case for Subjective Measurement or How Applied Behavior Analysis Is Finding Its Heart. Journal of Applied Behavior Analysis, 11, 203-214. http://dx.doi.org/10.1901\%2Fjaba.1978.11-203

Zacatelco, F. (2005). Modelo para la identificación del niño sobresaliente en escuelas de educación primaria [Model for the Identification of Gifted Students in Elementary School]. Unpublished Doctoral Thesis, Mexico City: Universidad Nacional Autónoma de México.

Zacatelco, F., Hernández, R., \& Acle, G. (2012). Enriquecimiento de la creatividad escrita en alumnos sobresalientes de tercer ciclo de primaria [Enrichment Creativity Written in Gifted Students in Third Grade of Elementary School]. In T. G. Acle (Coord.), Resiliencia en educación especial. Una experiencia en la escuela regular [Resilience in Special Education. An Experience in Elementary School] (pp. 433-463). Mexico: GEDISA-UNAM-FES Zaragoza.

Zavala, M. A. (2004). La detección de alumnos superdotados en las escuelas primarias [Detection of Gifted Students in Elementary Schools]. Unpublished Doctoral Thesis, Aguascalientes: Universidad Autónoma de Aguascalientes. 